\title{
Notes from the National Capital Area
}

\section{Anatoli M. Ilyashov}

University of the District of Columbia

The National Capital Labor History Society has inaugurated a series of lectures on Washington, D.C.'s labor heritage in its 1983-84 program of events. It is the first of its kind ever done here, in that the series systematically develops discussions featuring individuals who were key participants in the labor movement and trade unions of Washington, D.C. These include such labor sectors as federal workers, hotel and restaurant workers, service workers, retail workers, building trades and printers. Particular attention has been paid to the role of black labor, civil rights, and female labor in the making of the labor movement in the area. One of the aims of the series is to look beyond the apparent facade of labor peace in the nation's capital by recording the experiences of the trade unionists who took part in the labor struggles of the past. Much can be gained by this local "digging" and research, not only by local trade unionists and workers in the area who want to know more about their heritage, but also by teachers and students in the public school system who wish to focus on this subject as part of their curriculum. The series ends with a labor history bus tour done by the Washington Labor History Tours Project, a research project funded by the D.C. Community Humanities Council.

In propogating the use of oral history in the study of local history, Oral History in the Mid-Atlantic Region (OHMAR) will present its eighth annual workshop in late February with a program emphasizing the practical utilization of oral history techniques in the classroom setting. In cooperation with the Columbia Historical Society, the George Washington University Center for Washington Area Studies, and the Martin Luther King, Jr. Public Library, it will hold sessions on such subjects as life in segregated Washington, women's labor history, the many uses of oral history in the federal government, and neighborhood and ethnic studies. A major impetus for this workshop is the fact that all ninth grade students in the District of Columbia public schools are now required to take local history and do oral history interviewing. The workshop is therefore designed for primary and secondary school teachers. The potential for increased historical investigation in such fields as workers and labor is evident.

While labor historians are pondering the local labor movement, organized labor in the capital city is considering ways it may best get its message through nationally to its membership and to the public at large. In creating the Labor Institute of Public Affairs (LIPA), the AFL-CIO is hoping to give the American labor movement an effective voice in the electronic media and to take advantage of the rapidly expanding technology of modern electronic communications in reaching 
working people in this country. As the professional media production and distribution arm of the AFL-CIO, LIPA is developing new programs in the areas of television broadcasting, cable television, and video. Already, it has produced the television series "America Works" which focuses on social problems affecting labor and the economy. With the logo of "TV for America's Workers" its CableLINE Project found responsive audiences in the pilot programming in the three cities of Pittsburgh, Atlanta, and Seattle. For labor historians such an endeavor holds open the possibilities for new avenues of educating American workers and their children about their labor heritage. In the series entitled "Images of Labor," for example, selected labor documentaries having historical content were shown to audiences in those cities.

Last October 1983 a national conference sponsored by Workers Education Local 189 on Labor and the Peace Movement was held in Washington, D.C. at the National Education Association building. Featuring heads of unions such as Mary Futrell of the National Education Association and Henry Nicholas of the National Union of Hospital and Health Care Employees, District \#1199 (RWDSU), the conference sought to link the theoretical questions of the arms race with the practical aspects of what labor unions can really do in terms of action and education. Trade union representatives from Great Britain, France, and West Germany also participated in this dialogue, providing the invaluable international perspective on the issue. More importantly, this discussion has continued in the Washington area with the formation of the Washington Area Labor Committee on Central America and the Carribean. Composed mainly of members of national and local union staffs here in Washington, the Committee has provided a forum for discussion on trade union rights and peace in a politically volatile area of the world. 